\title{
DNA IS ASSEMBLED INTO GLOBULAR SUPRANUCLEOSOMAL CHROMATIN STRUCTURES BY NUCLEAR CONTENTS OF AMPHIBIAN OOCYTES
}

\author{
ULRICH SCHEER, JOHN SOMMERVILLE ${ }^{1}$ and ULRIKE MÜLLER
}

\begin{abstract}
Division of Membrane Biology and Biochemistry, Institute of Experimental Pathology, German Cancer Research Center, Germany, and 'Department of Zoology, University of St Andrews,
\end{abstract} St Andrews KY16 9TS, Scotland

\begin{abstract}
SUMMARY
The assembly of DNA into nucleosomal and supranucleosomal chromatin structures has been studied (i) by injection of circular DNA molecules (plasmids) into nuclei of Pleurodeles waltiii oocytes; and (ii) by in vitro incubation of plasmid molecules with the supernatant fraction from oocyte nuclei of Pleurodeles and Xenopus laevis, followed by purification of nucleoprotein structures formed with sucrose gradient centrifugation. In both types of experiments, spread preparations of the newly assembled and transcriptionally inactive chromatin, examined by electron microscopy, show dense globular higher order (supranucleosomal) packing forms. Under partially relaxing (low salt) preparation conditions granular chromatin subunits of about $30 \mathrm{~nm}$ diameter can be seen either as widely spaced particles or in closely packed aggregates. The transcriptionally inactive endogenous chromatin of chromomeres of lampbrush chromosomes is arranged in similar higher order chromatin units. A correlation is found between the sizes of the DNA molecule probes used and the numbers of nucleosomes and higher order globules in the assembled chromatin structures. After prolonged dispersion in low salt buffers, these globular chromatin units unfold into chains of 7-12 nucleosomes. The results support the concept that chromatin is arranged, under physiological ion concentrations as they are present in the nucleus, in supranucleosomal units of globular morphology.
\end{abstract}

When purified DNA molecules such as viral genomes, amplified ribosomal DNA (rDNA), mitochondrial DNA (mitDNA), or prokaryotic plasmids, with and without inserts of eukaryotic genes, are injected into nuclei of Xenopus laevis oocytes, they are assembled with the stored endogenous histones into chromatin with nucleosomal configuration [1-3]. Some kinds of injected molecules are, at least in part, efficiently and correctly transcribed [e.g. 2, 4-15]. Although difficult to quantitate, biochemical and electron microscopic evidence indicates that a large proportion of the injected DNA is not transcribed at all $[2,6,8]$. We became interested in the question as to whether this inactive DNA is, besides being assembled into a nucleofilament composed of a chain of nucleosomes [1-3], also condensed into higher order structures [e.g. 16-18], and how the structural organization of this newly assembled chromatin relates to that of the endogenous chromatin. In the present report we provide evidence for a compaction of DNA molecules into nucleosomes and also into higher order (supranucleosomal) structures of granular morphology. These higher order structures are observed after injection of DNA into oocyte nuclei, as well as after incubation of DNA with the supernatant fraction of oocyte nuclear homogenates. The latter in vitro 
system provides a useful means to study various structural and biochemical aspects of chromatin assembly at different levels of organization.

\section{MATERIAL AND METHODS}

\section{DNA}

The following plasmids and recombinant plasmids were used: (1) Plasmid pMB9; (2) the recombinant pWB 87 consisting of a $6.5 \mathrm{~kb}$ (kilobase) histone gene repeat from the sea urchin Echinus esculentus inserted into the plasmid Col E1 (kindly provided by $\mathrm{Dr}$ E. Southern, Mammalian Genome Unit, University of Edinburgh); (3) the recombinant pTp 6AAl consisting of rDNA sequences of Tetrahymena pigmentosa inserted into pBR 322 (kindly provided by Dr Martha Wild, Yale University, New Haven); (4) a recombinant plasmid consisting of the vector pMB9 with inserted yeast rDNA sequences (kindly provided by Drs M. Rosbash and L. Hereford, Brandeis University, Waltham). In order to facilitate measurement of their contour lengths, some plasmid preparations were relaxed by a limited digestion with DNAse I (grade 1, Boehringer, Mannheim). A $5 \mu \mathrm{g}$ sample of DNA of a solution containing $50 \mathrm{mM}$ Tris- $\mathrm{HCl}(\mathrm{pH} 8), 5 \mathrm{mM}$ $\mathrm{MgCl}_{2}$ was treated with $5 \times 10^{-5} \mu \mathrm{g} / \mathrm{ml}$ DNAse I at $37^{\circ} \mathrm{C}$. The reaction was then stopped after $10 \mathrm{~min}$ by addition of $300 \mu \mathrm{l}$ of a solution containing $0.2 \mathrm{M} \mathrm{NaCl}$, $10 \mathrm{mM}$ EDTA, $0.5 \%$ SDS, $10 \mathrm{mM}$ Tris- $\mathrm{HCl}$ ( $\mathrm{pH} 7.4$ ). The DNA was extracted with phenol and chloroform: isoamylalcohol (24:1), precipitated in $70 \%$ ethanol and spread for electron microscopy by the cytochrome $c$ droplet diffusion method [19]. DNA for injection was dissolved in " $3: 1$ saline" $(75 \mathrm{mM} \mathrm{KCl}$, $25 \mathrm{mM} \mathrm{NaCl}$ ) buffered to $\mathrm{pH} 7.2$ with $10 \mathrm{mM}$ Tris$\mathrm{HCl}$, at concentrations of $400 \mu \mathrm{g} / \mathrm{ml}$ and $10 \mu \mathrm{g} / \mathrm{ml}$.

\section{Injection}

Pleurodeles waltlii were obtained from a commercial source (Station d'acclimation et d'élevage, $79290 \mathrm{Ar}$ genton l'Eglise, France) and kept in large water tanks at $20^{\circ} \mathrm{C}$. A piece of ovary was removed from an anaesthetized female (0.1\% MS 222, Sandoz, Basle) and transferred into modified Barth medium [20] containing $50 \mathrm{U} / \mathrm{ml}$ each of penicillin, streptomycin and kanamycin. Individual oocytes with diameters ranging from 1.0 to $1.2 \mathrm{~mm}$ were mechanically freed from the surrounding follicular epithelium using two fine forceps. Centrifugation at $150 \mathrm{~g}$ for $10-20 \mathrm{~min}$ at room temperature brought the nucleus up to the animal pole, thereby facilitating the nuclear injection [11]. About $10 \mathrm{nl}$ of DNA solution was injected per oocyte nucleus (for technical details, see [20,21]), and the oocytes were subsequently incubated at room temperature for 3-24 h.

\section{In vitro assembly of chromatin}

Nuclei were manually isolated from full-grown oocytes of Pleurodeles waltiii or Xenopus laevis and collected in a small volume of ice-cold " $3: 1$ saline" in an Eppendorf reaction tube. A batch of 50 nuclei was homogenized in a total volume of $0.1 \mathrm{ml}$ by sucking the solution several times into an Eppendorf micropipette with a plastic tip, followed by centrifugation in a Beckman airfuge (Munich) at $100000 \mathrm{~g}$ for $1 \mathrm{~h}$. To the supernatant $0.5 \mu \mathrm{g}$ DNA was added and the mixture incubated at room temperature for $90 \mathrm{~min}$. DNA-protein complexes formed were then purified by centrifugation in a discontinuous sucrose gradient in $100 \mathrm{mM} \mathrm{NaCl}$, $10 \mathrm{mM}$ Tris- $\mathrm{HCl}(\mathrm{pH} 7.5), 1 \mathrm{mM}$ EDTA, and $1 \mathrm{mM}$ dithiothreitol. The gradient was formed by layers of $0.1 \mathrm{ml} 60 \%, 0.2 \mathrm{ml} 20 \%, 0.15 \mathrm{ml} 10 \%$, and $0.1 \mathrm{ml} 5 \%$ sucrose solutions in $0.7 \mathrm{ml}$ Beckman nitrocellulose tubes. Centrifugation was for $1 \mathrm{~h}$ at $30000 \mathrm{rpm}$ at $4^{\circ} \mathrm{C}$ in a Spinco SW $65 \mathrm{Ti}$ rotor using special adaptors (Beckman). Fractions of approx. $40 \mu \mathrm{l}$ were collected from the bottom of the centrifuge tubes.

\section{Electron microscopy}

Electron microscopic spreads of nuclear contents were made essentially according to Miller \& Bakken [22]. Two isolated nuclei were transferred into a drop of "pH 9 water" (ca $0.1 \mathrm{mM}$ sodium borate buffer, $\mathrm{pH}$ 8.5-9.0) placed on a siliconized glass slide at about $10^{\circ} \mathrm{C}$. After $2-10 \mathrm{~min}$ the dispersed nuclear contents underwent centrifugation through a cushion of $1 \%$ formaldehyde, $0.1 \mathrm{M}$ sucrose, $0.1 \mathrm{mM}$ borate buffer $(\mathrm{pH}$ 8.5-9.0) onto freshly glow-discharged, carbon-coated grids. After staining with $1 \%$ ethanolic phosphotungstic acid the grids were rotary-shadowed with $\mathrm{Pt} / \mathrm{Pd}$ at an angle of ca $8^{\circ}$ and examined in a Philips 301 or Zeiss EM 10 electron microscope. The instrument magnification was calibrated with a grating replica. Contour length measurements of DNA and chromatin were performed as described [23].

Chromatin assembled in vitro and purified by centrifugation in a sucrose gradient was prepared for electron microscopy under different ionic conditions following a method developed for visualization of SV 40 chromatin [24-26]. Fractions taken from the 20\% sucrose layer of the gradient (see above) contained the DNA-protein complexes formed and were either immediately fixed by adding glutaraldehyde to a final concentration of $0.2 \%$ or were diluted 5-10-fold with $1 \mathrm{mM}$ Tris- $\mathrm{HCl}$ ( $\mathrm{pH} 7.5$ ) prior to fixation. Nucleoprotein complexes were adsorbed to freshly glowdischarged carbon-coated grids by touching the surface of $10 \mu \mathrm{l}$ droplets placed on Parafilm for 5-10 min. The grids were then washed by placing them briefly on a water droplet, stained with uranyl acetate, dried from $95 \%$ ethanol, and finally metal shadowed. In order to increase the number of nucleoprotein complexes on the grids, especially after dilution with buffer, the material was centrifuged through a sucroseformaldehyde cushion as described above $(3500 \mathrm{~g}$, $40 \mathrm{~min})$.

\section{RESULTS}

Although the Xenopus system is well established for studying chromatin assembly 
and transcription of injected DNA (for references, see introductory paragraph), electron microscopic visualization of chromatin structure and of transcriptional events of injected DNA and endogenous chromatin is hampered by technical difficulties. Dispersal of chromosomal and extrachromosomal chromatin is difficult to achieve in this cell [27], due to the relatively high viscosity of the Xenopus oocyte nucleoplasm. To facilitate chromatin solubilization it is necessary to use prolonged dispersal times at very low salt conditions and/or the presence of certain ionic detergents, such as Sarkosyl or "Joy" [2, 3, 10, 22, 27]. These conditions, however, have decisive drawbacks. Higher order packing structures of chromatin are dependent on the presence of histone $\mathrm{H} 1$ and are unstable under low salt conditions [e.g. 18, 24-26, 28-30]. Inclusion of ionic detergents leads to a concentration-dependent release of histones from the DNA so that higher order structures may be affected as well as the basic nucleosomal organization [31]. The use of oocytes from other amphibian species, especially certain tailed amphibia with nuclear contents of very low viscosity, may overcome such problems. For example, electron microscopic spread preparations can be easily obtained when oocyte nuclei from various urodelan species are swollen for only a few minutes in low salt buffer (without the use of detergents), and the degree of unfolding of higher order chromatin structures can be readily studied. We have chosen Pleurodeles waltii. Oocytes of this newt are obtainable throughout the year, and the large lampbrush chromosomes can be used for examining the conformation and the transcriptional state of the endogenous chromatin [cf 32].

Injection of solutions containing low DNA concentrations $(10 \mu \mathrm{g} / \mathrm{ml}$, equivalent to $100 \mathrm{pg}$; i.e., nearly the $4 \mathrm{C}$ amount of DNA; cf [33]) into Pleurodeles oocyte nuclei apparently did not affect transcription of the endogenous rRNA genes, or of the lateral loops of the lampbrush chromosomes within $24 \mathrm{~h}$ after injection. In spread preparations the appearance of these transcriptional units was indistinguishable from that of control oocytes which were not centrifuged, injected and incubated (fig. 1a). Inactive chromatin, frequently arranged into dense aggregates, was predominant in chromomeres, and had the typical beaded appearance characteristic of a nucleosomal organization (fig. 1b). Especially when the nuclear contents were dispersed very briefly (up to $5 \mathrm{~min}$ ) under low salt conditions, a variable, often large proportion of this inactive chromatin appeared in distinct higher order globules with diameters of about 30 $\mathrm{nm}$ (fig. $1 b$ ). These globular packing units were either distinctly recognized, connected by fine strands sometimes revealing nucleofilament morphology (fig. $1 b, c$ ), or were in close contact forming chains of $30 \mathrm{~nm}$ beads (fig. $1 b$ ) or dense, thicker $(40-60 \mathrm{~nm})$ threads with irregular contours (fig. 1c).

When more DNA $(400 \mu \mathrm{g} / \mathrm{ml})$ was injected into Pleurodeles oocyte nuclei, rRNA genes were still not affected. In a variable proportion of the nuclei, however, we observed a progressive retraction of lateral loops of the lampbrush chromosomes and reduced densities of transcriptional complexes, indicating that injection of an excess amount of DNA may inhibit chromosomal transcription. Therefore, the DNA solutions used for the injection experiments were usually diluted to concentrations ranging from 10 to $50 \mu \mathrm{g} / \mathrm{ml}$.

The recombinant plasmid pWB 87 is shown in fig. $2 a$. The DNA circles have a mean contour length of $4.08 \pm 0.17 \mu \mathrm{m}$, cor- 


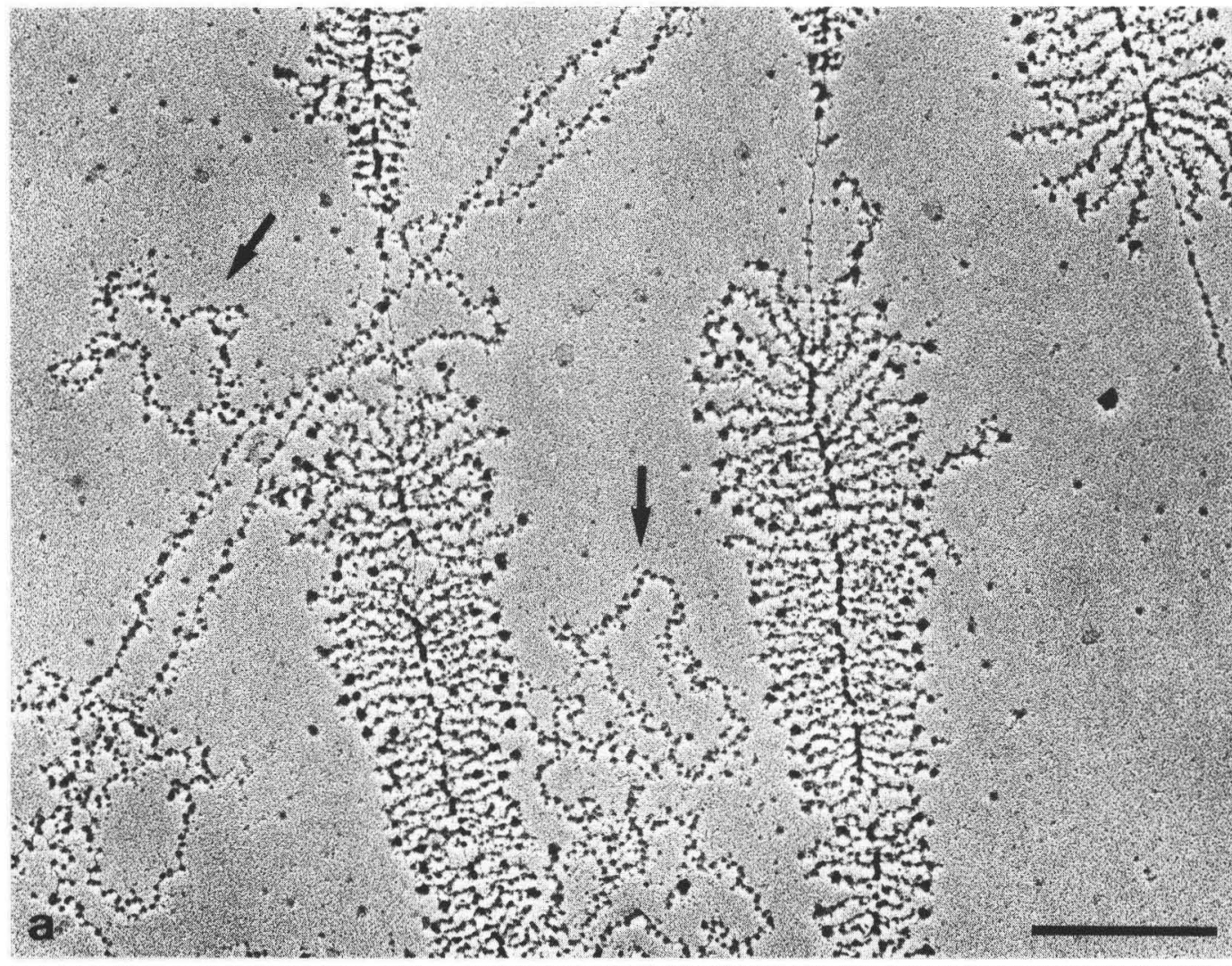

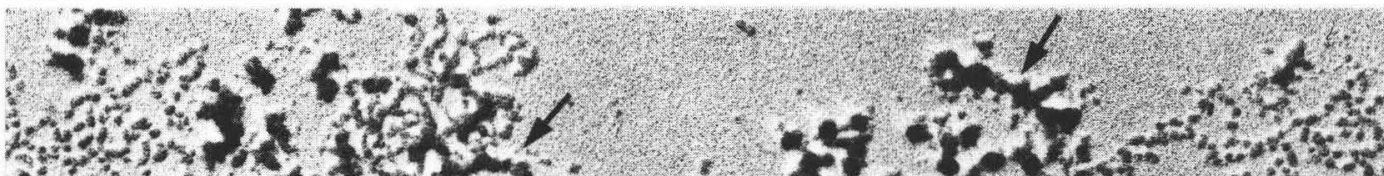

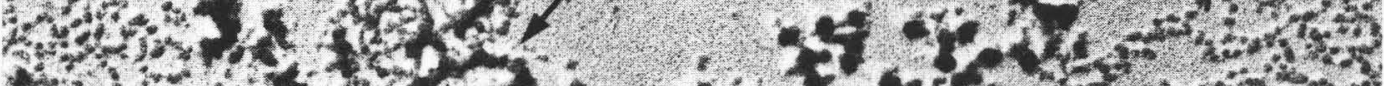

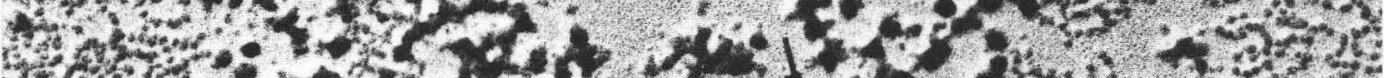

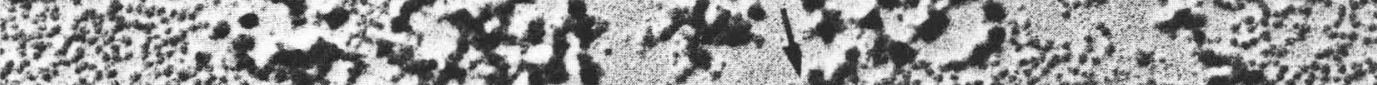

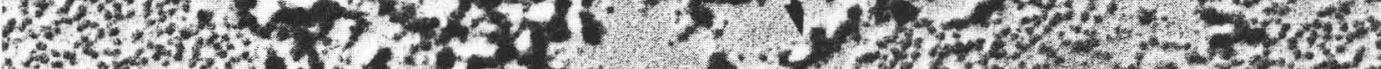

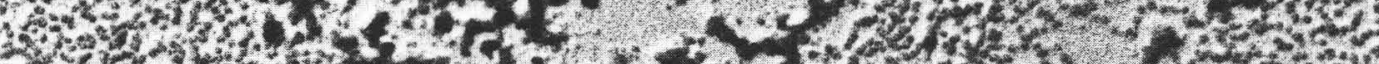

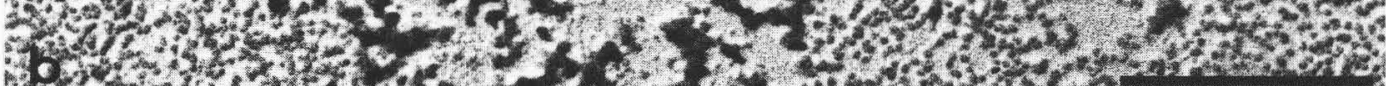

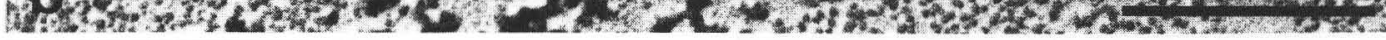

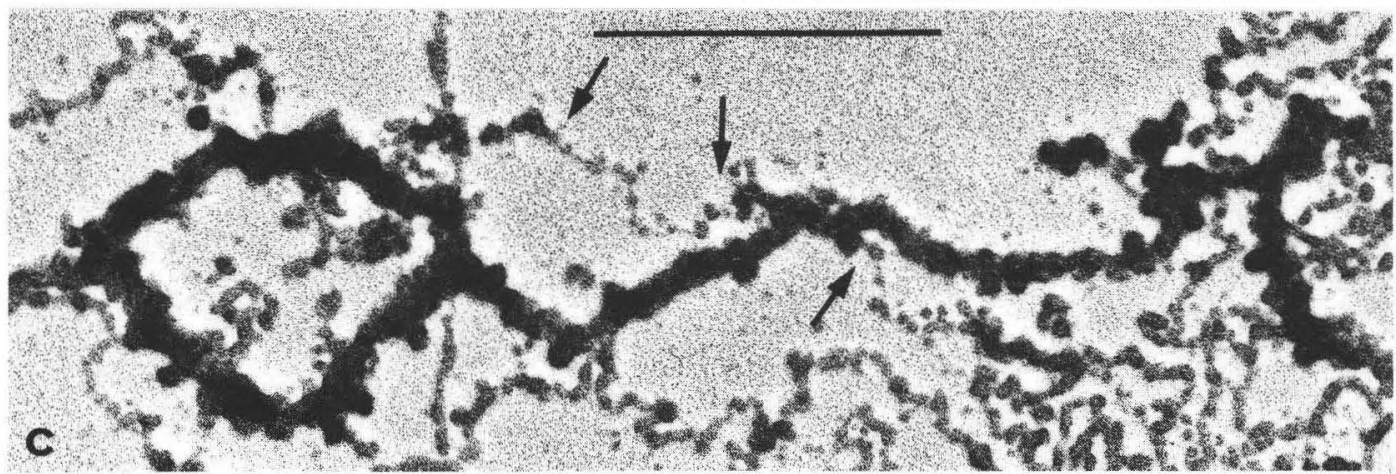

Exp Cell Res $129(1980)$ 
responding to $12.8 \mathrm{~kb}$ (converted according to data in ref. [34]). After injection into nuclei of Pleurodeles oocytes and spreading for electron microscopy numerous circular chromatin structures with the characteristic beaded appearance of nucleosomal chains were observed (fig. $2 b$ ), similar to the situation described upon injection of other kinds of circular DNA into Xenopus oocytes [1-3]. These chromatin rings had a mean contour length of $2.3 \pm 0.15 \mu \mathrm{m}$ and were composed of 66-76 nucleosomes (mean frequency, 72) of an approximate diameter of $12 \mathrm{~nm}$. Thus, under the specific low salt spreading conditions used, the newly assembled nucleofilament rings had a mean nucleosome density of 31 nucleosomes per micrometer, equivalent to a DNA compaction ratio (length of DNA in B-conformation/length of chromatin) of 1.9 (for related data, cf $[2,3,24-26,35,36])$. From this it can also be calculated that each nucleosomal unit contains, on the average, 178 bp of DNA, about 59 bp of which are located in the internucleosomal 'linker' region. These figures agree reasonably well

Fig. 1. Appearance of (a) transcriptionally active; $(b, c)$ inactive endogenous (amphibian) chromatin after injection of $10 \mathrm{nl}$ of DNA solution $(10 \mu \mathrm{g} / \mathrm{ml}$; pMB9/ yeast rDNA plasmid) into nuclei of Pleurodeles oocytes. Nuclei were isolated $6 \mathrm{~h}$ after injection and their contents spread for electron microscopy by $(a)$ long ( $20 \mathrm{~min}$ ) or $(b, c)$ short (ca $5 \mathrm{~min}$ ) exposure to low salt buffer ( $\mathrm{pH} 9$ borate buffer). Fully active rRNA genes in extended, largely non-nucleosomal configuration occur side by side with inactive, nucleosomally arranged chromatin strands (endogenous chromatin) and rings containing the injected plasmid DNA (two plasmids are denoted by arrows). In the peripheral portions of the transcriptionally inactive chromomere regions of lampbrush chromosomes two different forms of chromatin packing are seen, i.e. $(b, c)$ nucleosomes and larger supranucleosomal globules approx. $30 \mathrm{~nm}$ in diameter. Where these globules are closely juxtaposed, they form chains of ca $30 \mathrm{~nm}$ beads (e.g. at the arrows in $(b))$ or thicker threads (c) (40$60 \mathrm{~nm}$ ). Regions of structural transitions between higher order globules and nucleosomes are frequently seen (e.g. at the arrows in (c)). Bars, $0.5 \mu \mathrm{m}$. with the biochemically determined DNA content of Xenopus oocyte nucleosomes after nuclease digestion $[36,37]$.

Besides open chromatin circles with the characteristic 'beads-on-a-string' pattern, we found a variable proportion of chromatin units that were more aggregated (fig. $2 c-i)$. Their relative amount in spread preparations was usually higher after short times of dispersal of the nuclear contents. The large-beaded chromatin circles appeared occasionally highly twisted and coiled. Generally, they revealed a composition of distinct globular structures with diameters of about $30 \mathrm{~nm}$, so that individual nucleosomes could no longer be detected (fig. $2 c-h)$. Depending on the specific spreading conditions, nucleosomal beads and higher order globules were occasionally seen on the same chromatin unit (e.g. fig. $2 e$, see also fig. $3 c, h)$. Although it was difficult to determine the number of these higher order globules precisely, we usually counted 6-10 per chromatin unit (fig. $2 f-h$ ), indicating a content of 7-12 nucleosomes per supranucleosomal globule.

When differently sized plasmids were injected into oocyte nuclei, a dependence of both the contour length of the circular nucleosomal chains and the size of the supranucleosomal aggregates on the size of the DNA used was found. For example, fig. $3 a$ shows the plasmid pMB 9 having a contour length of $1.73 \pm 0.05 \mu \mathrm{m}(5.4 \mathrm{~kb})$ which, after injection into Pleurodeles oocyte nuclei, appeared in chromatin circles containing an average of 31 nucleosomes (fig. $3 b$ ) and in dense aggregates in which a maximum of four $30 \mathrm{~nm}$ globules was observed (fig. $3 c-e$ ). On the other hand, the much larger recombinant of plasmid pMB 9 with yeast rDNA (fig. $3 f$; contour length $4.89 \pm$ $0.1 \mu \mathrm{m}, 15 \mathrm{~kb})$ was converted into much larger chromatin circles containing an aver- 

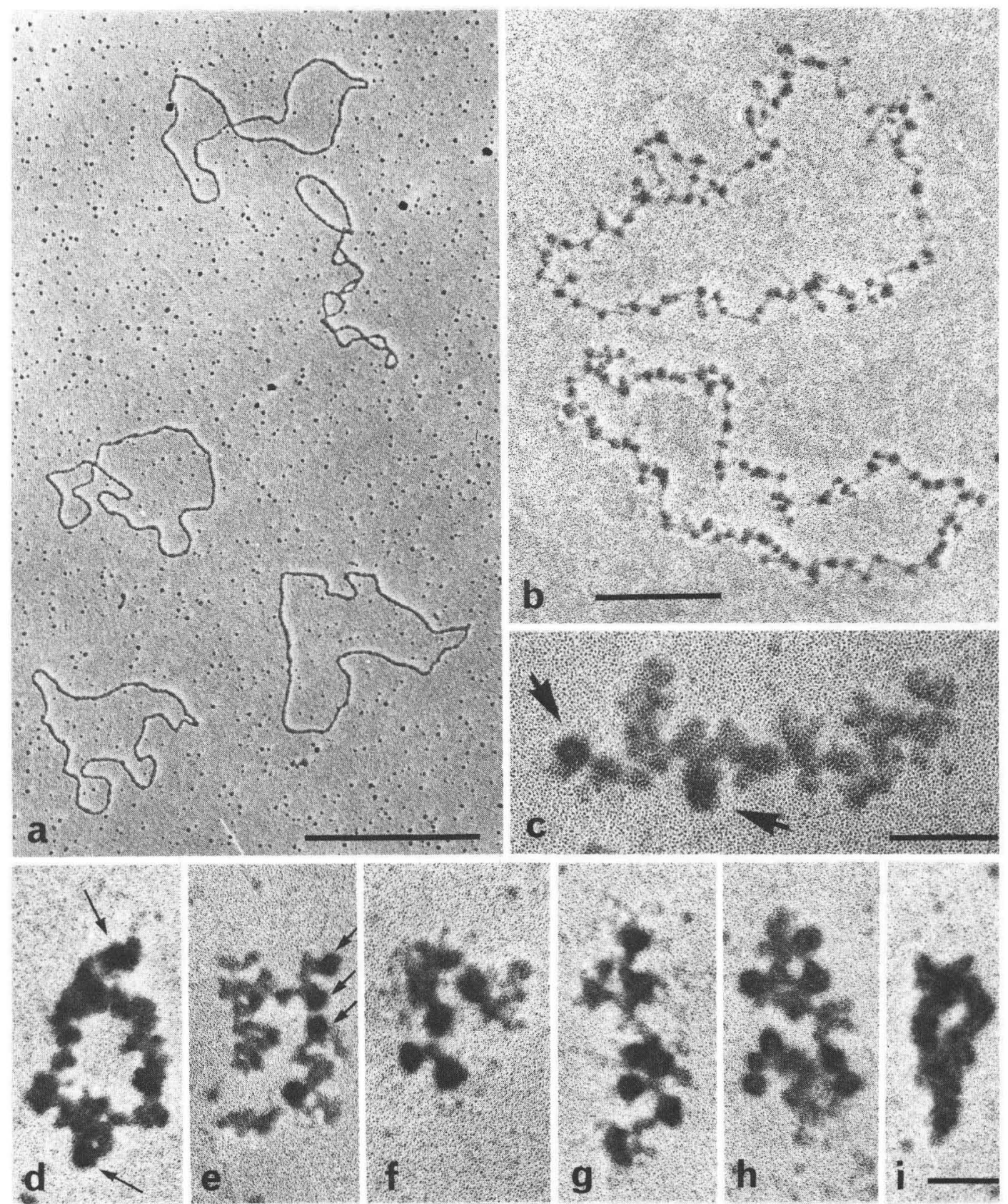

Fig. 2. Conversion of the DNA of (a) recombinant plasmid pWB 87 into nucleosomal and higher order chromatin structures upon injection into oocyte nuclei of Pleurodeles, seen in spread preparations made $3 \mathrm{~h}$ after injection. The plasmids are recovered in the form of $(b)$ open beaded chromatin circles or of $(c-i)$ dense aggregates. In these somewhat irregularly shaped ag- gregates frequently distinct, globular higher order structures of diameters of approx. $30 \mathrm{~nm}$ are seen (e.g., arrows in $c-e$ ). Close packing of the supranucleosomal globules sometimes leads to the formation of $(d, i) \mathrm{ca}$ $30 \mathrm{~nm}$ thick circular chromatin fibres. Bars, (a) $1 \mu \mathrm{m}$; (b) $0.2 \mu \mathrm{m}$; $(c, i) 0.1 \mu \mathrm{m}$. (d-i) Magnified to the same scale. 

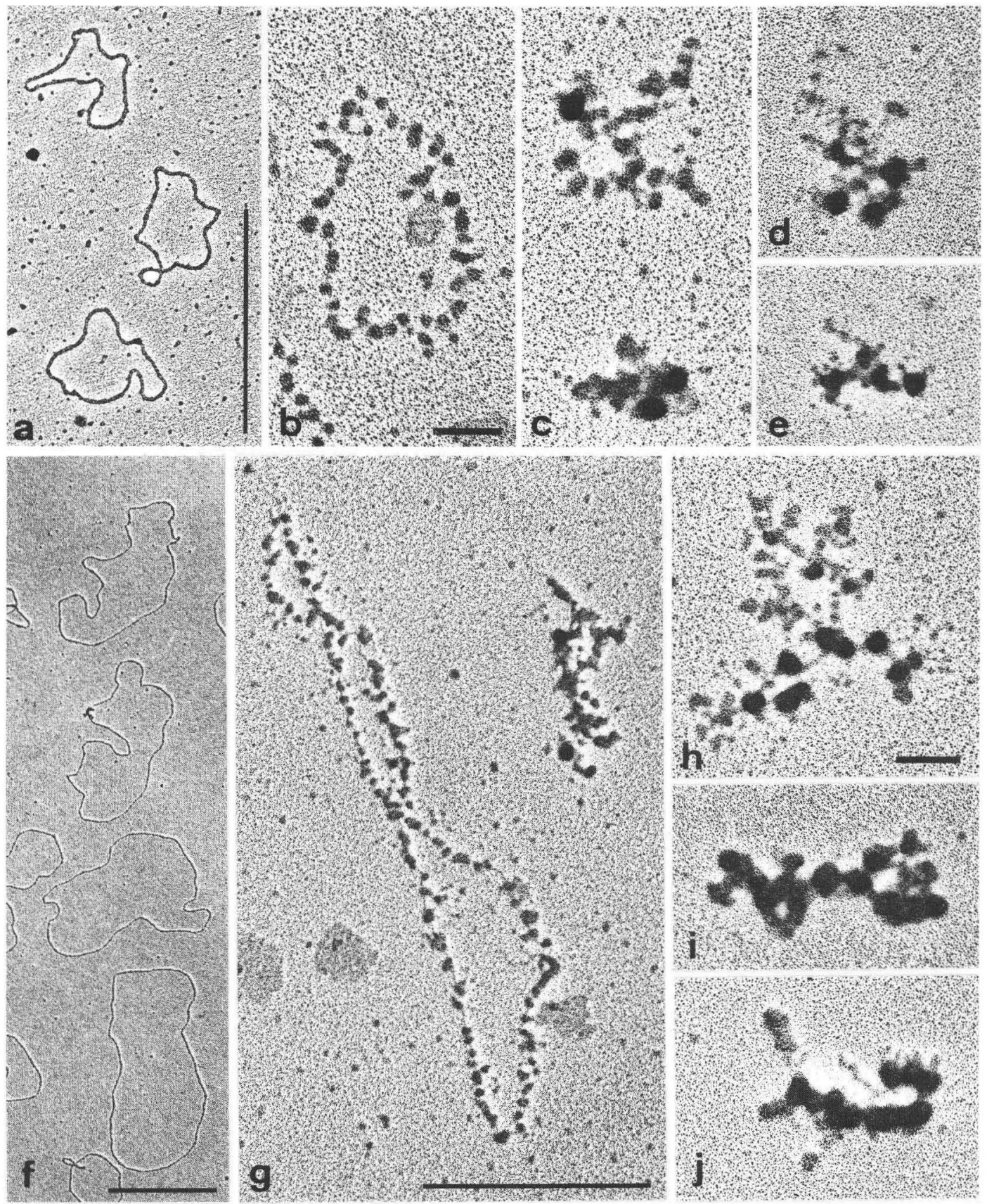

Fig. 3. Correlation of the sizes of newly assembled nucleosomal and supranucleosomal chromatin structures with the contour lengths of the specific plasmids used for injection into oocyte nuclei of Pleurodeles. The small plasmid pMB9 $(a)$ (contour length $1.73 \pm 0.05$ $\mu \mathrm{m})$ is converted into $(b)$ beaded chromatin rings with an average of 31 nucleosomes and, $(c-e)$ moreover, into higher order structures containing not more than four distinct $30 \mathrm{~nm}$ globular particles. Note the simultaneous occurrence of nucleosome-like beads and higher order globules in the same chromatin strand (e.g., (c) upper part). The large plasmid shown in $(f)$ (pMB9/yeast rDNA recombinant; contour length $4.89 \pm 0.1 \mu \mathrm{m}$ ) is converted into large beaded chromatin circles with an average of $(g) 83$ nucleosomes and, at $(h-j)$ higher order level, into the large aggregates of ca $30 \mathrm{~nm}$ globules shown at different degrees of unravelling during the low salt treatment. Note that open beaded chromatin rings and higher order aggregates can occur side by side $(g)$. Bars, $(a, f) 1 \mu \mathrm{m} ;(g) 0.5$ $\mu \mathrm{m} ;(b, h) 0.1 \mu \mathrm{m}$. ( $b-e$ and $h-j)$ Magnified to the same scale 


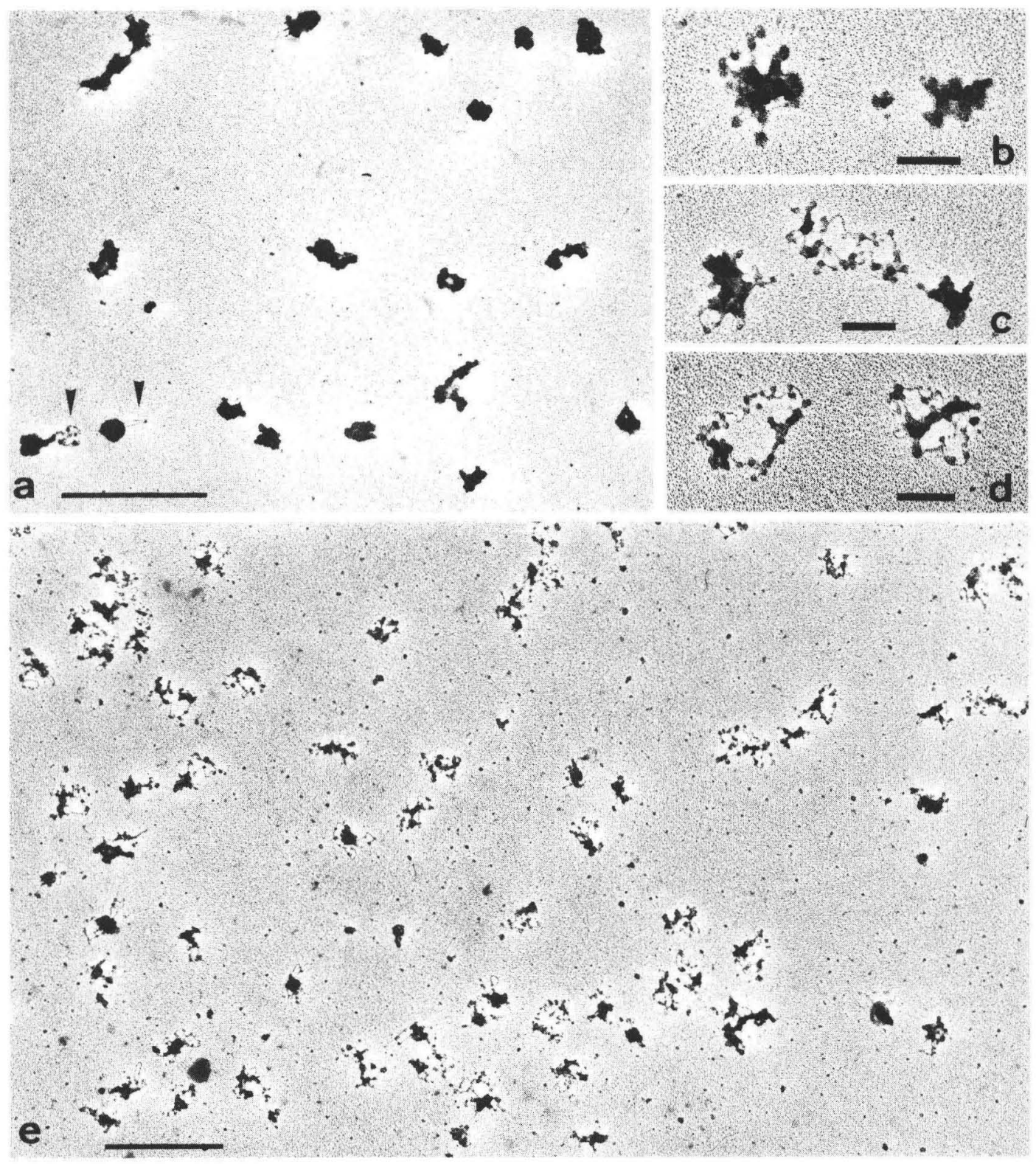

Fig. 4. Nucleoprotein complexes formed after in vitro incubation of DNA of the plasmid pTp 6AA 1 (contour length $2.9 \pm 0.3 \mu \mathrm{m}$ ) with the supernatant fraction obtained from Pleurodeles oocyte nuclei and then purified by centrifugation in sucrose gradients. When spread under physiological salt concentrations, the newly assembled plasmid chromatin appears in the form of very dense particles $((a)$, arrowheads point to small loops of DNA or beaded chromatin extending from these particles). Upon prolonged incubation at lower ionic strength $(50 \mathrm{mM} \mathrm{NaCl})$ these very dense complexes unfold into smaller, often granular subunits and reveal regions of chains of nucleosome-like beads $(b-e)$. Bars, $(a, e) 0.5 \mu \mathrm{m} ;(b-d) 0.1 \mu \mathrm{m}$. 
age of 83 nucleosomes (fig. $3 g$ ) and also formed much larger aggregates of higher order chromatin globules (fig. $3 g-j$ ).

The higher compaction of the nucleosomal chromatin rings into such globular supranucleosomal structures was sometimes directly seen in situations in which both structural states occurred side by side (fig. $3 g$ ). With all plasmid DNA molecules examined, the dimensions of the individual higher order aggregates were somewhat variable, even on the same grid, apparently depending on the specific degree of packing of the supranucleosomal globules (e.g. fig. $3 i, j)$. Occasionally, partly unfolded higher order chromatin aggregates were seen in which nucleosomal and supranucleosomal globules occurred on the same DNA molecule, revealing continuities between $30 \mathrm{~nm}$ globules and nucleosomes (fig. $3 c, h$ ).

To demonstrate the nuclear localization of the components and factors involved in the conversion of DNA molecules into nucleosome-like and supranucleosomal chromatin organization, and to exclude the possibility that disturbance by the injection per se has contributed to this phenomenon, we developed an in vitro incubation system, at physiological ionic strength, using a $100000 \mathrm{~g}$ supernatant of homogenates of manually isolated nuclei from Pleurodeles and Xenopus oocytes. Control experiments showed that, after centrifugation of nuclear supernatants without DNA added, any particulate structures were absent in the $20 \%$ sucrose boundary fraction. When $0.5 \mu \mathrm{g}$ of plasmid DNA, with or without inserted eukaryotic sequences, was incubated for 90 min with the supernatant from 50 nuclei of Pleurodeles or Xenopus oocytes, followed by centrifugation in a sucrose gradient made up in a buffer of physiological ionic strength, DNA-protein complexes were found to be enriched in the $20 \%$ sucrose boundary layer. Aliquots taken therefrom and fixed directly by adding glutaraldehyde revealed, by examination in the electron microscope, a rather homogeneous population of highly condensed nucleoprotein complexes, with either spheroidal or prolate and extended shapes (fig. 4a). Occasionally, loops of DNA or short strings of nucleosome-like beads were seen to emerge from the periphery of these particles, indicating their chromatinous nature. When incubated in $50 \mathrm{mM} \mathrm{NaCl}$ for prolonged periods of time (ca $12 \mathrm{~h}$ ) before mounting for electron microscopy, these large dense aggregates revealed smaller subgranules similar to substructures described in SV40 chromatin (compare fig. $4 b-e$ with fig. 7 of ref. [26]) and exhibited partial unfolding. Intermediates between highly compact and partially unravelled nucleofilament structures are shown at higher magnifications in fig. $4 b-d$ and, in a survey of the preparation, in fig. $4 e$. After a tenfold dilution with $1 \mathrm{mM}$ Tris-buffer (resulting in a final ionic strength of $10 \mathrm{mM} \mathrm{NaCl}$ ) and centrifugation on to electron microscopic grids, the reconstituted chromatin complexes were unravelled in large parts, thereby demonstrating nucleosome-like beads (fig. $5 a-d$ ). However, in many cases local aggregates of compacted and dense morphology as well as individual $30 \mathrm{~nm}$ large higher order globules were still seen in these relaxed chromatin rings, indicating that some higher order associations were more resistant to the low salt treatment (fig. $5 a-d$ ). After spreading at low ionic strength the distances between nucleosome-like beads appeared with considerable variations (e.g. fig. $5 a-d)$. At the moment we do not know whether unusually extended non-beaded ('linker') regions, which were repeatedly observed, represent regions of unfolded nucleosome particles or reflect regions of in- 


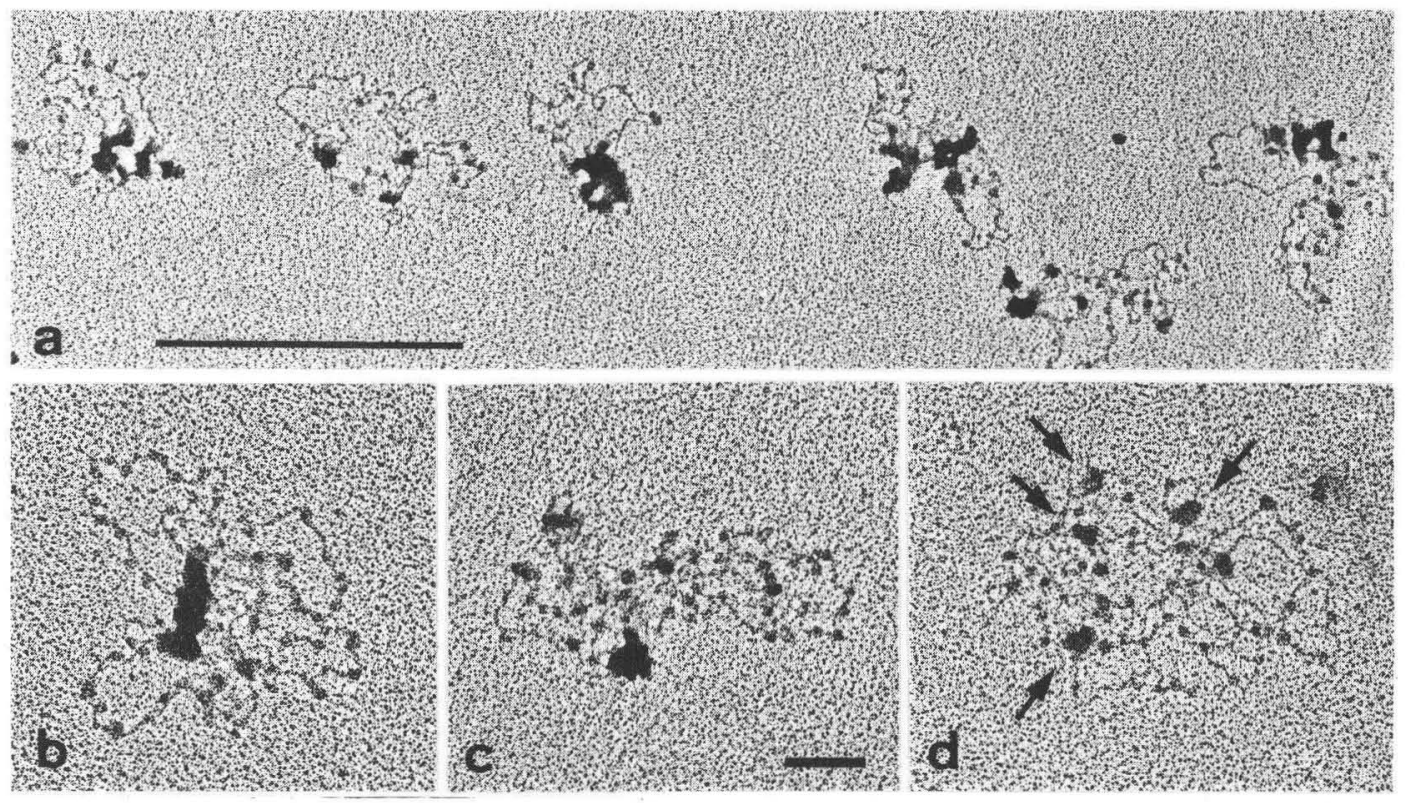

Fig. 5. Appearance of DNA-protein complexes newly formed in vitro (conditions as described in the caption to fig. 4) after purification in sucrose gradient, tenfold dilution with $1 \mathrm{mM}$ Tris-buffer, and centrifugation on to electron microscopic grids. The nucleoprotein complexes are more or less unfolded into beaded chains of nucleosome-like morphology. Compact and unfolded regions can occur on the same DNA molecule. Some granular higher order structures of diameter ca $30 \mathrm{~nm}$ are still present (e.g. denoted by the arrows in $(d)$ ). Bars, (a) $0.5 \mu \mathrm{m}$; (c) $0.1 \mu \mathrm{m}$. (b-d) Magnified to the same scale. complete chromatin assembly, perhaps as a result of limited histone supply.

\section{DISCUSSION}

Our results show that circular DNA molecules of varying size and sequence are converted into nucleoprotein structures after injection into nuclei of Pleurodeles oocytes, in a similar manner as previously described in Xenopus oocytes [1-3]. In addition, we have shown that incubation of the plasmids with the $100000 \mathrm{~g}$ supernatant from homogenates of isolated oocyte nuclei of both Pleurodeles and Xenopus also results in the formation of such complexes which, at low ionic strength, appear with a nucleosomelike morphology, similar to the results obtained with egg homogenates of Xenopus by
Laskey and colleagues [38, 39]. When prepared under physiological ionic conditions $(0.1 \mathrm{M})$, however, these nucleoprotein complexes occur in configurations clearly different from the beaded appearance of extended nucleosomal chromatin. The nucleoprotein particles appear as highly compacted and very dense aggregates of spheroidal or prolate shape with a mean overall particle size that is correlated with the contour length of the specific DNA probe used. Granular substructures are sometimes observed, especially after partial unfolding at somewhat lower ionic strength, and the most predominant substructure seems to be a globular particle approx. $30 \mathrm{~nm}$ in diameter. When these newly formed large nucleoprotein particles are unfolded by incubation in very low salt con- 
centrations, they are transformed into chromatin rings with the characteristic 'beadson-a-string' morphology of nucleosomal chains. From these observations we conclude that the nucleoplasm of amphibian oocytes transforms added DNA not only into a nucleosome-like configuration but also, further, into higher order structures of globular morphology. Since the in vitro incubation assay described here includes only the supernatant proteins from manually isolated nuclei of oocytes instead of proteins from whole eggs $[38,39]$, it is clear that the components and factors involved in the chromatin assembly process, such as histones and probably also the nucleosome assembly-promoting protein described by Laskey et al. [40], are located in the nuclear sap. This conclusion is supported by observations that large amounts of histones are stored in the nucleus of Xenopus oocytes [41] and that the acidic protein of approximate molecular weight 30000 described by the Cambridge group as 'nucleosome assembly factor' [40] is located specifically and in usually high concentrations in oocyte nuclei of Xenopus [42, 43] and other amphibia including Pleurodeles waltlii [44]. It has also been shown that the factor required for the introduction of negative supercoils into relaxed SV40 DNA in the presence of histones is located in Xenopus oocyte nuclei [45].

The relationship of the globular higher order structures of the nucleoprotein newly assembled from oocyte nuclear material vis-à-vis similarly sized granular units described in various kinds of transcriptionally inactive chromatin [e.g. 18, 29, 30, 35, 46$50]$, including chromomere regions of the oocyte lampbrush chromosomes (fig. 1b, $c$ of this study and ref. [32]), is not clear and will have to be examined by biochemical methods. Specifically, it has to be shown that the structural changes observed during transition from the $30 \mathrm{~nm}$ nucleoprotein globule to chains of nucleosome-like beads reflects the presence of histone $\mathrm{H} 1$ in this newly assembled chromatin material (for comparison see $[24-26,29,49,51])$. In view of reports describing nucleosome-like structures in chromatin artificially reconstituted from histones $\mathrm{H} 3$ and $\mathrm{H} 4$ alone [e.g. 52, 53] it cannot be excluded at the moment that the beaded conformation seen in chromatin newly assembled from nucleoplasmic material may contain only histones $\mathrm{H} 3$ and $\mathrm{H} 4$. Studies are in progress to answer this question by purification of the newly assembled nucleoprotein complexes as described here and characterization of the protein associated with the added DNA.

We thank Dr Hanswalter Zentgraf (Institute for Virus Research, German Cancer Research Center, Heidelberg) for experimental co-operation and Dr Duri Rungger (Department of Animal Biology, University of Geneva) for an introduction to the injection technique. We thank Professor H. G. Callan (St Andrews) and Professor W. W. Franke (Heidelberg) for encouragement and helpful discussions.

\section{REFERENCES}

1. Wyllie, A H, Laskey, R A, Finch, J \& Gurdon, J B, Dev biol 64 (1978) 178 .

2. Trendelenburg, M F \& Gurdon, J B, Nature 276 (1978) 292.

3. Zentgraf, $H$, Trendelenburg, M F, Spring, $H$, Scheer, U, Franke, W W, Müller, U, Drury, K C \& Rungger, D, Exp cell res 122 (1979) 363.

4. Mertz, J E \& Gurdon, J B, Proc natl acad sci US 74 (1977) 1502.

5. Colman, A, Eur j biochem 57 (1975) 85

6. Brown, D D \& Gurdon, J B, Proc natl acad sci US 74 (1977) 2064.

7. De Robertis, E M \& Mertz, J E, Cell 12 (1977) 175.

8. Gurdon, J B \& Brown, D D, Dev biol 67 (1978) 346

9. Brown, D D \& Gurdon, J B, Proc natl acad sci US 75 (1978) 2849.

10. Trendelenburg, M F, Zentgraf, H, Franke, W W \& Gurdon, J B, Proc natl acad sci US 75 (1978) 3791.

11. Kressmann, A, Clarkson, S G, Pirrota, V \& Birnstiel, M L, Proc natl acad sci US 75 (1978) 1176.

12. Probst, E, Kressmann, A \& Birnstiel, M L, J mol biol 135 (1979) 709 .

13. Rungger, D \& Türler, H, Proc natl acad sci US 75 (1978) 6073. .

14. De Robertis, E M \& Olson, M V, Nature 278 (1979) 5700. 
15. Melton, D A \& Cortese, R, Cell 18 (1979) 1165.

16. Klug, A, Phil trans roy soc London B 283 (1978) 233.

17. Worcel, A, Cold Spring Harbor symp quant biol 42 (1978) 313.

18. Hozier, J, Renz, M \& Nehls, P, Chromosoma 62 (1977) 301 .

19. Lang, D \& Mitani, M, Biopolymers 9 (1970) 373.

20. Gurdon, J B, J embryol exp morphol 36 (1976) 523.

21. - The control of gene expression in animal development. Clarendon Press, Oxford (1974).

22. Miller, O L \& Bakken, A H, Acta endocrinol suppl. 168 (1972) 155.

23. Trendelenburg, M F, Scheer, U, Zentgraf, H \& Franke, W W, J mol biol 108 (1976) 453

24. Griffith, J D, Science 187 (1975) 1202.

25. Keller, W, Müller, U, Eicken, I \& Zentgraf, H, Cold Spring Harbor symp quant biol 42 (1978) 227.

26. Müller, U, Zentgraf, H, Eicken, I \& Keller, W, Science 201 (1978) 406

27. Scheer, U, Trendelenburg, M F, Krohne, G \& Franke, W W, Chromosoma 60 (1977) 147.

28. Brasch, K, Exp cell res 101 (1976) 396.

29. Renz, N, Nehls, P \& Hozier, J, Proc natl acad sci US 74 (1977) 1879.

30. Strätling, W H, Müller, U \& Zentgraf, H, Exp cell res 117 (1978) 301 .

31. Scheer, U, Cell 13 (1978) 535.

32. Scheer, U, Sommerville, J \& Bustin, M, J cell sci 40 (1979) 1.

33. Sommerville, J, Int rev biochem 15 (1977) 79.

34. Stüber, D \& Bujard, H, Mol gen genet 154 (1977) 299.

35. Scheer, U \& Zentgraf, H, Chromosoma 69 (1978) 243.

36. Reeder, R H, McKnight, S L \& Miller, O, Cold Spring Harbor symp quant biol 42 (1978) 1174.

37. Reeves, R, Biochemistry 17 (1978) 4908.

38. Laskey, R A, Mills, A D \& Morris, N R, Cell 10 (1977) 237.
39. Laskey, R A, Honda, B M, Mills, A D, Morris, N R, Wyllie, A H, Mertz, J E, De Robertis, E M \& Gurdon, J B, Cold Spring Harbor symp quant biol 42 (1978) 171.

40. Laskey, R A, Honda, B M, Mills, A D \& Finch, J T, Nature 275 (1978) 416.

41. Woodland, H R \& Adamson, E D, Dev biol 57 (1977) 118.

42. Krohne, G \& Franke, W W, Proc natl acad sci US 77 (1980) 1034.

43. Mills, A D, Laskey, R A Black, P \& De Robertis, E M, J mol biol 139 (1980) 561.

44. Krohne, G \& Franke, W W, Exp cell res. In press (1980).

45. Baldi, M I, Mattoccia, E \& Tocchini-Valentini, G P, Proc natl acad sci US 75 (1978) 4873.

46. Franke, W W, Scheer, U, Trendelenburg, M F, Spring, H \& Zentgraf, H, Cytobiologie 13 (1976) 401.

47. Franke, W W, Scheer, U, Trendelenburg, M F, Zentgraf, H \& Spring, H, Cold Spring Harbor symp quant biol 42 (1978) 755.

48. Kiryanov, G I, Manamshjan, T A, Polyakov, V Yu, Fais, D \& Chentsov, Ju S, FEBS lett 67 (1976) 323.

49. Meyer, G F \& Renz, M, Chromosoma 75 (1979) 177.

50. Zentgraf, H, Müller, U \& Franke, W W, Eur j cell biol 20 (1980) 254.

51. Christiansen, G \& Griffith, J, Nucleic acid res 4 (1977) 1837.

52. Sollner-Webb, B, Camerini-Otero, R D \& Felsenfeld, G, Cell 9 (1976) 179.

53. Bina-Stein, M \& Simpson, R T, Cell 11 (1977) 609.

Received May 17, 1979

Revised version received March 24, 1980

Accepted April 1, 1980 